\title{
Assessing impact of climate change on the wheat production in the Yellow River Basin, China
}

\section{Avaliação do impacto da mudança climática na produção de trigo na bacia do rio Amarelo, China}

\author{
Lingyue Wang ${ }^{1}$; Xiaoliu Yang ${ }^{2 *}$; Ruina Zhao ${ }^{3}$
}

\begin{abstract}
Conflicts between water supply and water demand are intensifying in irrigation districts along the Lower Yellow River, China, due to climate change and human activities. To ensure both adequate food supply and water resource sustainability in the region, this paper investigated the relationship between wheat yield and meteorological variables in 7 provinces within the Yellow River Basin. The key meteorological variables that influenced wheat yield were identified, and the regression functions between climate relevant wheat yield and these variables were established. Combining with the climate change scenarios in the future, the impact of climate change on crop yield were assessed. To cope with limited water resources in this region, it is necessary to properly irrigate crops based on soil water content and take full advantage of precipitation and surface runoff during the summer maize season.
\end{abstract}

Key words: Economic impact. Grain crops. Agriculture.

\section{Resumo}

Conflitos entre o abastecimento e a demanda de água vêm se intensificando nas regiões irrigadas ao longo do Baixo Rio Amarelo, na China, devido às mudanças climáticas e às atividades humanas. Para garantir o fornecimento adequado de alimentos e a sustentabilidade dos recursos hídricos na região, esse artigo avaliou a relação entre o rendimento de trigo e as variáveis meteorológicas nas sete províncias da Bacia do Rio Amarelo. As principais variáveis meteorológicas que influenciam o rendimento do trigo foram identificadas e funções de regressão foram estabelecidas. Combinando com cenários futuros de mudanças climáticas, o impacto dessas mudanças no rendimento do trigo foi avaliado. Para lidar com recursos hídricos limitados nessa região, é necessário irrigar adequadamente as lavouras com base no teor de água do solo e aproveitar ao máximo a precipitação e o escoamento durante a safra de milho do verão.

Palavras-chave: Impacto econômico. Produção de grãos. Agricultura.

1 Ph.D. Student, College of Urban and Environmental Science, Peking University, Beijing, China. E-mail: wanglingyue@pku. edu.cn

2 Prof. Dr., College of Urban and Environmental Science, Peking University, Beijing, China. E-mail: xlyang@urban.pku.edu.cn

3 Post-Graduate, College of Urban and Environmental Science, Peking University, Beijing, China. E-mail: rnzhao@urban.pku. edu.cn

* Author for correspondence 


\section{Introduction}

Agriculture is the most sensitive and vulnerable socio-economic sector with regard to climate change (MENG et al., 2016). Wheat planted widely in the Yellow River Basin, where impacts of climate change on wheat yield are studied having a significant meaning (LYU et al., 2014). Primary contents are as followed: 45-year trend of climate change from 1961 to 2005 in the entire Yellow River Basin, the correlation between wheat yield and climate factors, and forecasting the economic impacts of future climate change on wheat production.

Factors affecting wheat yield consist of socioeconomic and meteorological factors. The latter includes accumulated temperature, light, temperature, precipitation and so on (PAN et al., 2015; SU, 2015; WANG et al., 2015; ZHAO et al., 2014). Not considering accumulated temperature and light relatively stable factors, temperature and precipitation as independent variables are chosen in the study, SPSS stepwise regression method is used to find the major factors impacting wheat production in the Yellow River. The related factors contain average temperature and precipitation in the whole growing season, the coldest month temperature and precipitation, the hottest month temperature and precipitation as well as seasonal temperature and precipitation.

These meteorological factors have advantages and disadvantages on wheat yield. Positive impacts on wheat production mainly embody accelerating of the growth and development of wheat due to an increase in temperature, nutrition and growth phase being ahead of schedule, the whole growth period being extended, as well as increase of acreage suitable for planting. But climate change is more harm than good, making the amplitude of evaporation and precipitation increase, the soil be relatively severe drought, pests and diseases add, and eventually wheat yield adversely be affected.

Assessing climate impacts are recognized as basis for developing adaptation policy and increasingly becoming major areas of scientific concerns, e.g. valuation of climate impacts on wheat production (LUO et al., 2009; WEI et al., 2009; YANG et al., 2008; LUDWIG; ASSENG, 2006), on trout production (BENHIN, 2008), and on agriculture (FICKLIN et al., 2009; MESTRESANCHÍS; FEIJÓO-BELLO, 2009; MASUTOMI et al., 2009; MIRAGLIA et al., 2009; BENHIN, 2008; FISCHER et al., 2007). These studies help understanding the costs and benefits of the adaptation policy for farmers, rural areas and food security (REIDSMA et al., 2010).

Weather is the most important cause of yearto-year variability in climate relevant crop productivity, even in high-yield and high-technology environments (DU et al., 2017; LIANG et al., 2018). In terms of the Yellow River Basin, which is located in the mid-latitudes of northern hemisphere, duration of sunshine is long, light conditions are sufficient to meet the growth and yield formation of winter wheat. Annual mean sunshine hours vary from 2000 to 3000 hours, its inter-annual changes are not large, so the impact on crop yield was not significant (WU; ZHOU, 2007).

Temperature affecting the geographical distribution of plants and photosynthetic productivity is one of the major environmental factors (REZAEI et al., 2018). The chemical reaction rates of various activities depend on temperature, and the temperature has a direct impact on the level of plants absorbing water and minerals (PAN et al., 2015; PAYMARD et al., 2018). Temperature changes include daily or yearly variation of air temperature; the report focuses on studying impact of yearly variation of air temperature on crop production. Climate warming extending the growing season throughout the year is favorable for those who have unlimited growth habit or perennial crops (e.g. cotton) (HATFIELD; DOLD, 2018; HUSSAIN; AHMAD, 2018), as well as for areas with inadequate heat condition; but also is detrimental to the cultivation of crops of the short growth period, because high temperatures cause growth of crops accelerated, fertility shortened, and yield will decline (YU et al., 2013). 
This study examines the climate challenge facing the Yellow River Basin in terms of wheat production.

\section{Materials and Methods}

Study area

The Yellow River Basin in North China is one of the most dynamic, fast growing regions in the world today. Originating in the Bayan Har Mountains in Qinghai province of Western China, it flows through nine provinces, and it empties into the Bohai Sea near the city of Dongying in Shandong province. The Yellow River basin has an east-west extent of about $1,900 \mathrm{~km}$ and a north-south extent of about $1,100 \mathrm{~km}$. Its total drainage area is about 752,546 $\mathrm{km}^{2}$. But with $800,000 \mathrm{~km}^{2}$ of basin area, 120 million of population, intense economic activity relying on agriculture to provide livelihoods for a large segment of the population and dependence on water resources to drive development, the basin is highly vulnerable to the harsh impact of climate change (Figure 1).

Figure 1. Location of Yellow River Basin, China, with mean annual rain ( $\mathrm{mm})$, drained area, main irrigation district, meteorological stations, and hydrological stations.

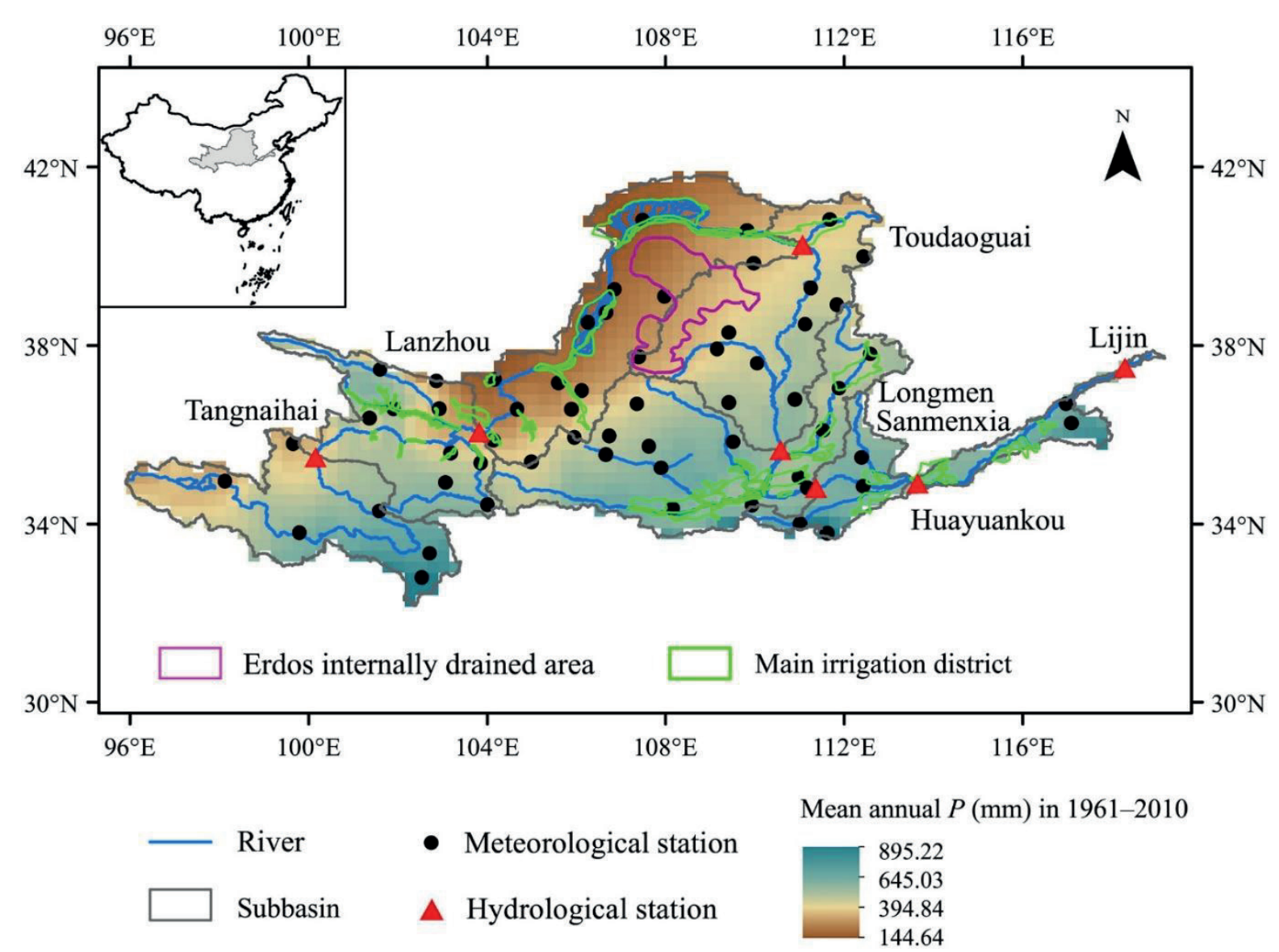




\section{Crop yield data}

Wheat crop yield data for the 1951-2007 period were obtained from the National Centre for Agricultural Scientific Data Sharing.

\section{Observed climatic data}

Climate data for the 1951-2007 period were obtained from 64 meteorological stations in the Yellow River Basin.

\section{Climate change scenarios}

The climate change scenario was provided by an EU-China River Basin Management
Programme, Yellow River Climate Change Scenario Development Project, in which climate conditions such as temperature and precipitation were projected under A2 and B2 scenarios in the next 100 years (CHEN et al., 2010).

\section{Methodology}

Figure 2 shows the technology roadmap of the study. The study aimed to determine the key meteorological variables affecting wheat yield and established a regression function between climaterelated wheat yields and these variables.

Figure 2. Technology roadmap of the study.

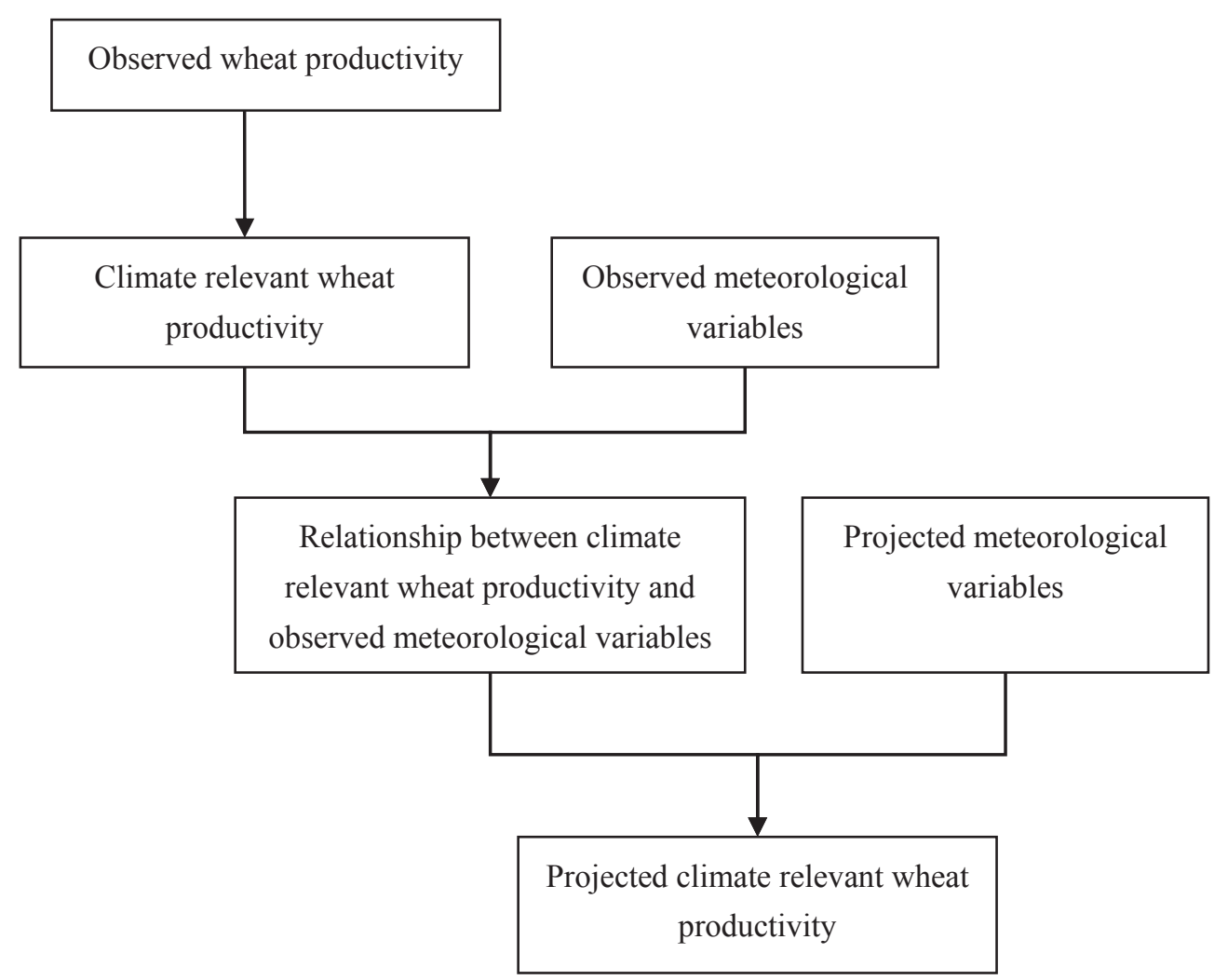




\section{Climate relevant crop productivity}

Crop yield is formed under the joint action of many other ecological environmental factors and human society, including the meteorological factors, soil factors, terrain factors, biological factors and human factors. As agricultural meteorologist study impacts of light, temperature, water and other weather factors on crop yield with the statistical methods, crop yield will often be artificially broken down into trend and climate relevant productivity, Crop production determined by meteorological factors is defined as climate relevant crop productivity. Crop actual productivity (Y) can be broken down into three components, namely:

$$
\mathrm{Y}=\mathrm{Y}_{\mathrm{t}}+\mathrm{Y}_{\mathrm{w}}+\epsilon
$$

Where, $Y_{t}$ presents trend productivity with progressive and relative stability, mainly reflecting the level of agricultural technology to improve the production; is fluctuations in production with year to year volatility, mainly due to inter-annual change of meteorological factors; $\in$ as random factors generally ignored. Therefore, the type simplified is as followed:

$$
Y=Y_{t}+Y_{w}
$$

Trend productivity is decided by relatively stable and less variable inertia factors (mainly the agricultural technology) and shows a positive function for the time. Taking rid of trend productivity can effectively remove the productivity due to advances in agricultural and other natural or unnatural factors in the sequence of productivity, and then we can highlight the meteorological factors. In this study, five-year linear moving average method is used to calculate the trend yield and weather production.

Impacts of meteorological factors on Climate relevant wheat productivity

Throughout the development period for each crop or some growth period, there is a lowest temperature, that is the minimum temperature of beginning of life; At the same time, there is an upper limit temperature, that is life, growth or developmental biology maximum temperature; optimal temperature of crop exuberant life activity, growth and development is a biological optimum temperature. These three temperatures collectively referred to as the three-point temperature of crop development. Below the lowest temperature and above the maximum temperature, crop life activities are inhibited or even completely stop, and if temperature continues to increase or reduce, lethal temperature would be reached and crop is injured or even dead. Three-point temperature is different with variety, growth period, and physiological and ecological conditions (Table 1).

The three point temperatures are not the same for the same kind of crop at different developmental stages, due to differences in crop organ domain or the reproductive process. Three-point temperature of plant growth and three point temperatures of photosynthesis are different, but generally the same. Three-point temperature of wheat in different developmental stages is shown in Table 1. 
Table 1. Three-point temperature (lowest, optimum and maximum) of wheat (general) and in the crop different growing stages.

\begin{tabular}{lccc}
\hline & Lowest temperature $\left({ }^{\circ} \mathrm{C}\right)$ & Optimum temperature $\left({ }^{\circ} \mathrm{C}\right)$ & Maximum temperature $\left({ }^{\circ} \mathrm{C}\right)$ \\
\hline Wheat & $3-5$ & $20-24$ & $30-35$ \\
\hline Growing stage & & & \\
\hline Seeding emergency & $1-2$ & $15-22$ & $30-32$ \\
Tillering stage & $2-4$ & $14-18$ & $18-20$ \\
Heading and flowing & $9-12$ & $18-20$ & 32 \\
Filling stage & $12-14$ & $18-22$ & $26-30$ \\
Mature & 15 & $20-24$ & 30 \\
\hline
\end{tabular}

(Data from Xiaoguang Yang, Huning Yu, CHINA AGRICULTURAL DATA SHARING CENTRE - AGRIDATA).

\section{Results and Discussion}

Over the past few decades the basin has seen higher temperatures and a sharp rise in the frequency of extreme weather events including droughts and floods. Without urgent action to address this pressing issue, the basin will face a difficult future marked by declining freshwater and crop yields.

Wheat is adaptable and is grown nearly everywhere in China, but the main growing area is in North China, where half of the total crop area is located. Because of the short frost-free period in the basin, it has long been the practice there to interplant the wheat crop with an autumn-harvest crop. However, where no irrigation is available, it is often necessary to follow the system of three crops in two years since even in the southern part of each provinces of the basin there is insufficient soil moisture available to support two crops a year. On the Loess Plateau in the Yellow River Basin (Shanxi, Shaanxi and Gansu), there are large areas of dry land, and the most general cropping system there is to harvest four crops every three years. Shandong and Henan, which are located in the lower reaches and benefit from more favourable natural conditions than other regions in the basin, were in a dominant position in wheat production. Wheat yields grew fairly steadily in Shandong from 1979 to 2001. In 2001, however, Shandong's production plummeted, dropping to production levels of 11 years earlier, in 1990. In the 1979-2001 period, Henan's wheat production also went up - although hardly in a steady line.

Moisture conditions are basic environmental factors of crop growth and development, the moisture play an extremely important significance on crop growth and yield formation, both as environmental conditions for plant to survive, but also the composition of plants. It is the raw material for photosynthesis and transport carriers absorbing various inorganic nutrients, but also the media necessary for regulating body temperature and stomata closure of plants. Water is not only directly involved in the lives of the activities and crop yield formation, and has a major impact on the potential of the light and geothermal resources effectively, even under certain conditions, changing into a dominant factor, thus affecting agricultural production in the whole situation. Water is often the stress factor; precipitation is a major part of water resources, directly affecting agricultural production. The increase or decrease of precipitation varies in different regions, including positive and negative effects. The amount of rainfall has less impact on agricultural production in relatively humid areas, but it is crucial factor in dry areas.

$400 \mathrm{~mm}$ isohyet of annual mean precipitation is an important agro-climatic boundary in China, generally along the Daxing'anling West Road 
southward and through the Tongliao, Hohhot, Yulin, Lanzhou, Yushu and Lhasa. North and west of this line are mostly arid and semi-arid regions, such as central Inner Mongolia, Ningxia, and northern Shaanxi in the Yellow River valley and so on. South and east of the line are generally humid and semihumid area, including Shanxi Province, southern Shaanxi, Henan, Gansu, Sichuan and Shandong Province in the Yellow River.

\section{Climate relevant wheat productivity}

Figure 3 describes the fitting curve between the actual productivity and trend production in Henan Province.

Climate relevant wheat productivity is equal to the actual productivity minus trend productivity. Figure 4 shows wheat yield changes yearly in Shanxi Province. Figure 5 shows crop weather yield in 7 provinces within the Yellow River Basin.

Figure 3. Relation between wheat actual productivity and trend productivity (unit: $1 \times 10^{9} \mathrm{~kg}$ ).

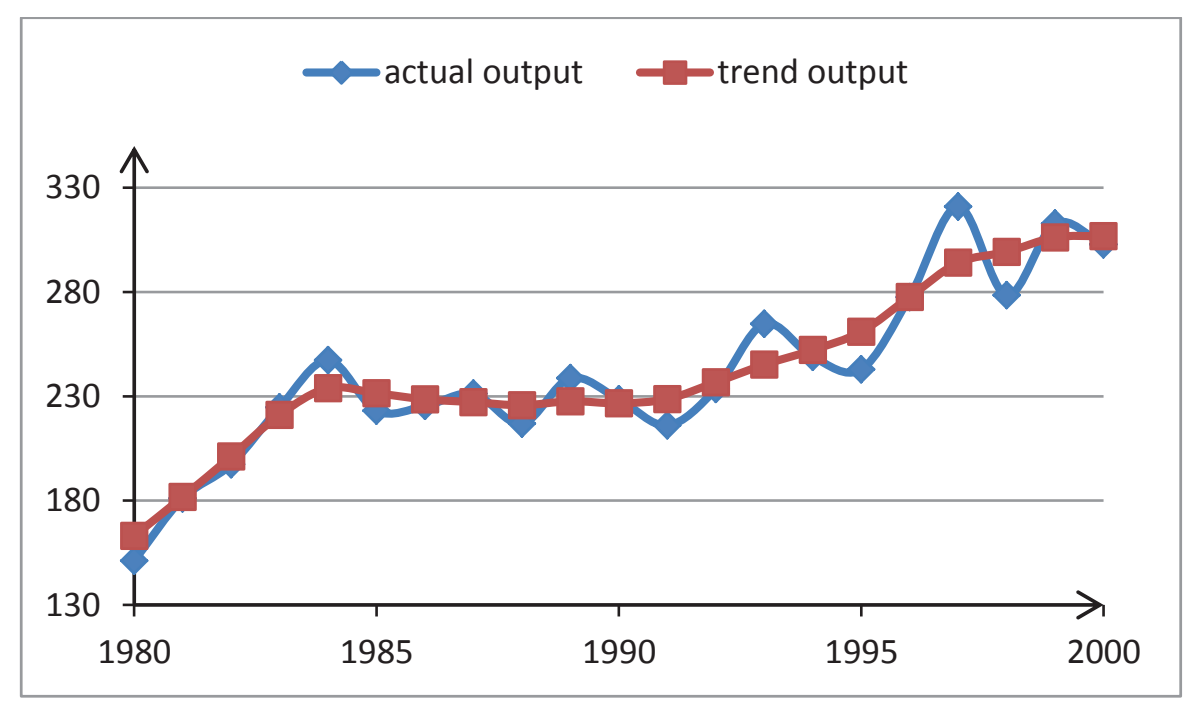

Figure 4. Climate relevant wheat productivity change in Henan Province (unit: $\mathrm{kg} \mathrm{ha}^{-1}$ )

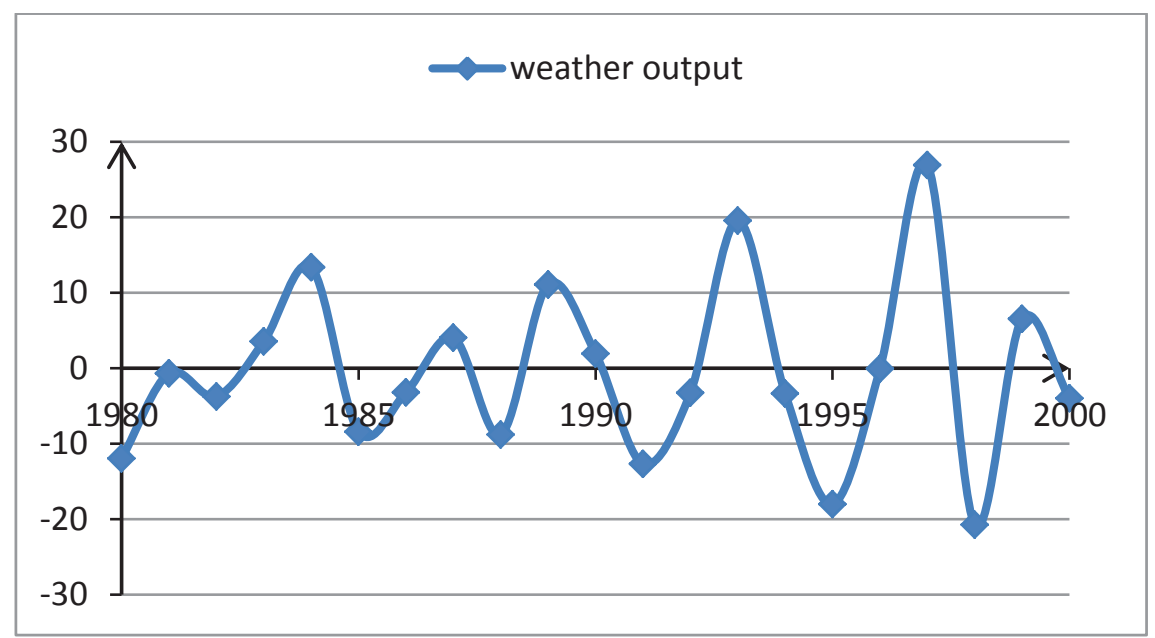


Figure 5. Climate relevant wheat productivity in 7 provinces within the Yellow River Basin (unit: $\mathrm{kg} \mathrm{ha}^{-1}$ )
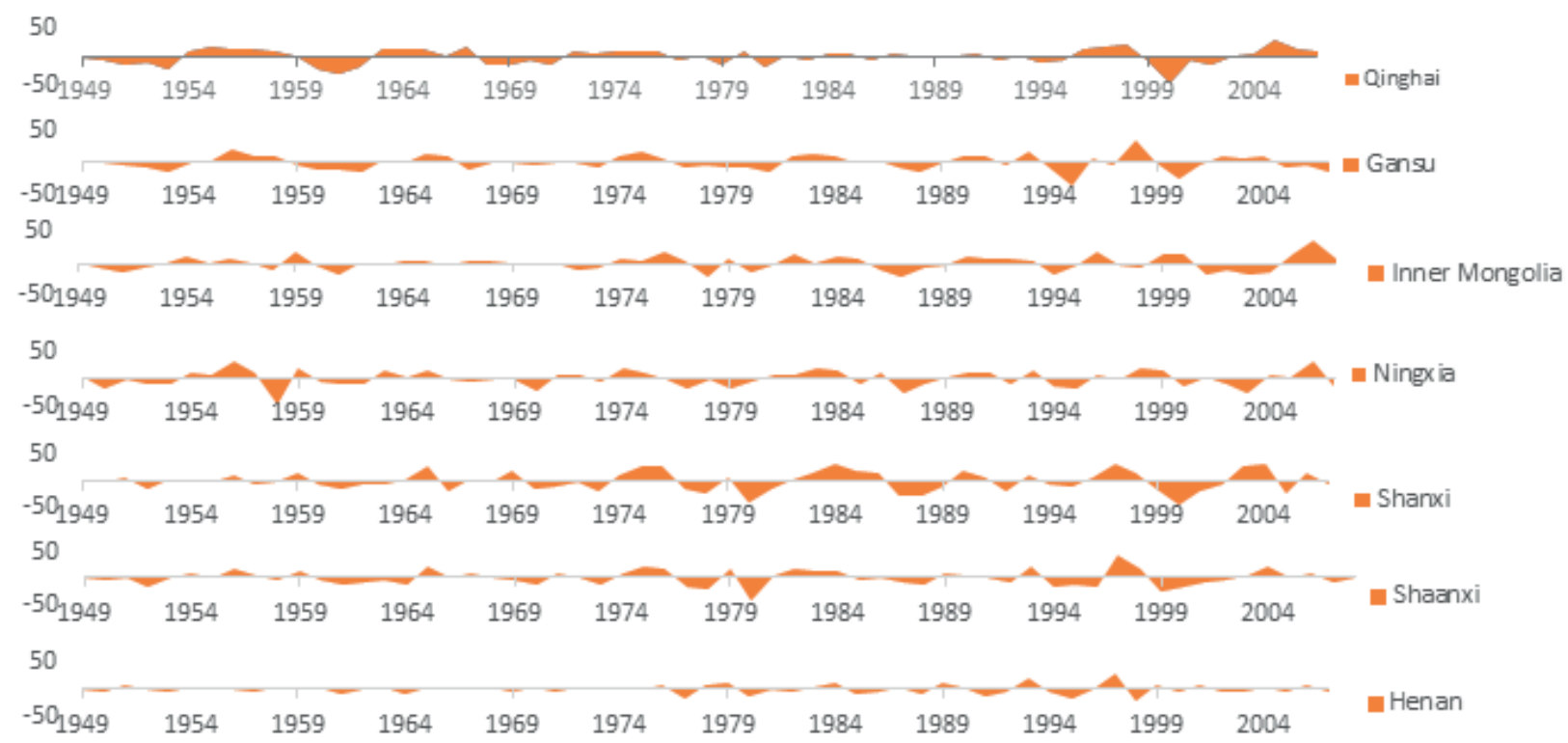

Identifying the main meteorological variables that affect wheat productivity

Relationship between temperature and wheat production

Figure 6 shows the relationship between the wheat productivity yield and air temperature during $1951-2005$, showing a linear correlation in Gansu Province, Inner Mongolia Autonomous Region and Shaanxi Province. Wheat productivity in Gansu Province has a negative correlation with the average temperature in May. Wheat productivity in Inner Mongolia has a negative correlation with the average temperature in April. Wheat yield in Shaanxi Province is negatively related to air temperature in October. 
Figure 6. Relationship between wheat climate relevant productivity and air temperature in a single month: a) correlation between average temperature in May and climate relevant productivity in Gansu; b) correlation between average temperature in April and climate relevant productivity in Inner Mongolia; c) correlation between average temperature in October and climate relevant productivity in Shaanxi.

a)

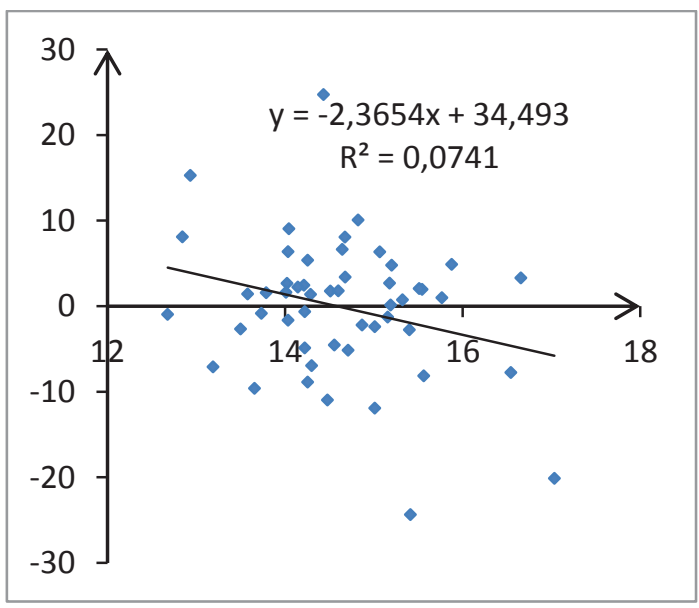

b)

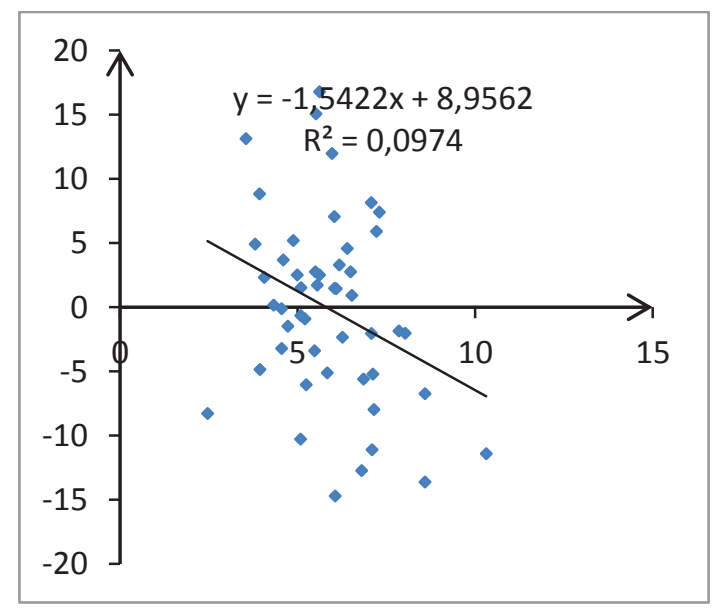

c)

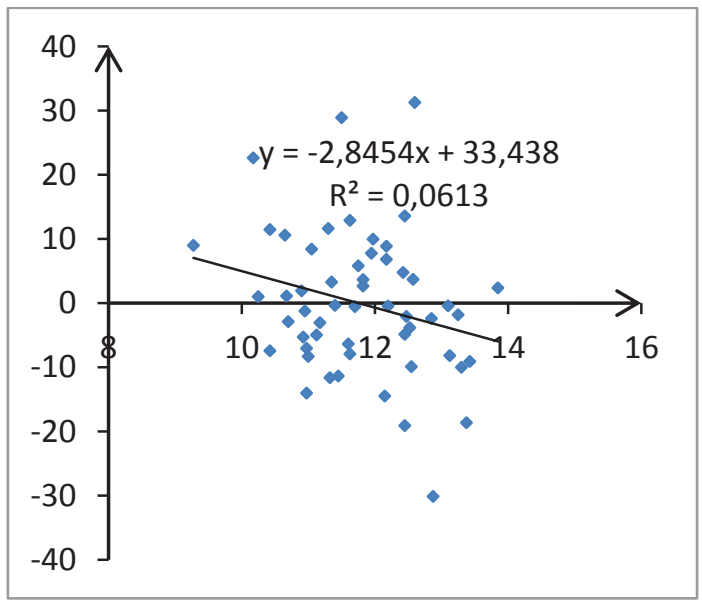

Winter wheat in Gansu province in May is at the transition of heading and filling stage. The annual average temperature in May is $14.0^{\circ} \mathrm{C}$ during 1985 2005 , the lowest temperature reaches $12.1^{\circ} \mathrm{C}$ in 1993 , and the highest temperature is up to $16.5^{\circ} \mathrm{C}$ in 2000 . Direct response of a physiological activity of wheat to temperature is shorter growth duration. In the filling stage of wheat, high temperature accelerates development rate, shorten the birth process, reduce dry matter accumulation time, and productivity will decline. In addition, the temperature increases soil evaporation, so that water deficit increases in late growth of wheat, green leafy reduces ability to assimilate and eventually productivity decline. Wheat production in the province has a negative correlation with average temperature in May.

Spring wheat is mainly planted in Inner Mongolia Autonomous Region, which enters the jointing and heading stage in April. The annual average temperature in April is $15.9{ }^{\circ} \mathrm{C}$ during $1985-2005$, the lowest temperature gets to $14.8^{\circ} \mathrm{C}$ in 1991 , and the highest temperature is $18.1{ }^{\circ} \mathrm{C}$ in 1986 . High temperature is bad for matter accumulation and yield formation in the vegetative growth phase. Relation between the province's wheat productivity and the temperature in April is linear negative correlation. 
Relationship between precipitation and wheat production

Figure 7 describes relationship between wheat yield and precipitation in various provinces, including Qinghai, Gansu, Inner Mongolia, Shaanxi, Shanxi and Henan Province. Most of these provinces are located in China's arid and semi-arid area, wheat yield is primarily related to precipitation.

Figure 7. Relationships between Wheat Output and Precipitation: a) correlation between average precipitation in March and climate relevant productivity in Qinghai; b) correlation between average precipitation in September and climate relevant productivity in Gansu; c) correlation between average precipitation in June and climate relevant productivity in Inner Mongolia; d) correlation between average precipitation in February and climate relevant productivity in Shaanxi; e) correlation between average precipitation in September and climate relevant productivity in Shanxi; f) correlation between average precipitation in October and climate relevant productivity in Henan.

a)

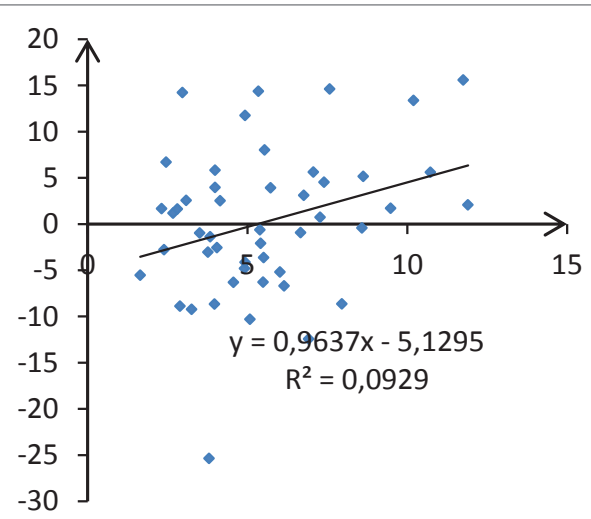

c)

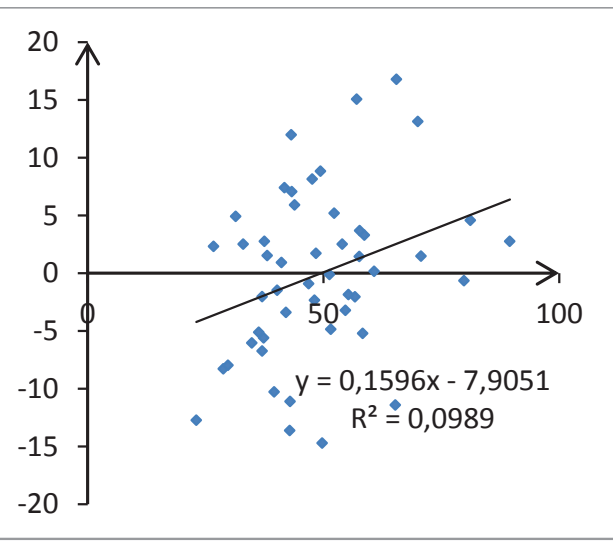

e)

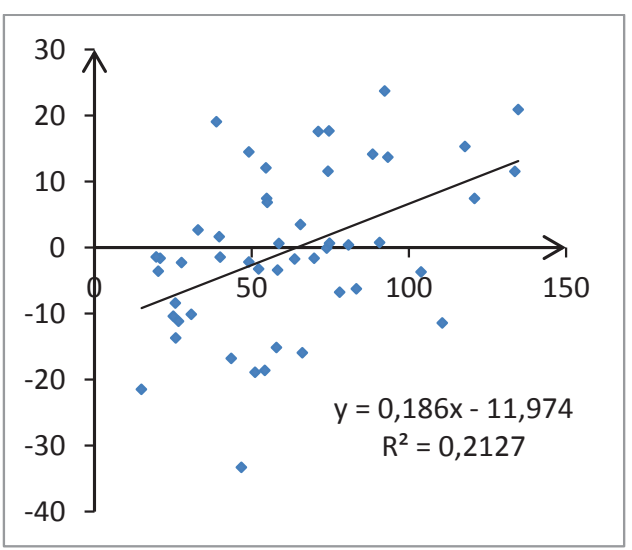

b)

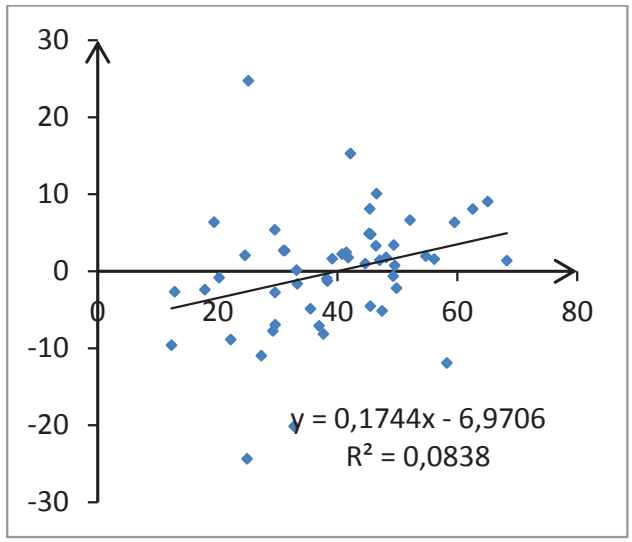

d)

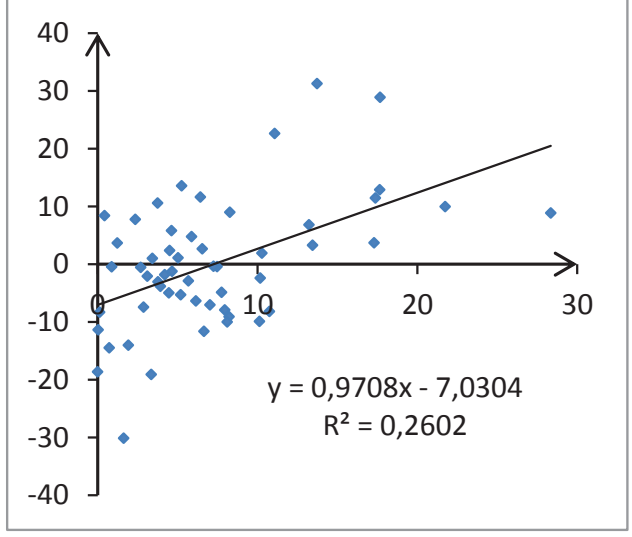

f)

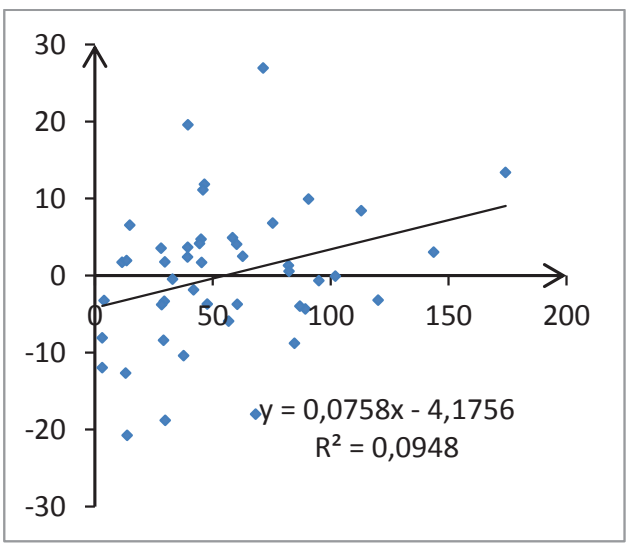


Both winter and spring wheat can be planted in Qinghai Province, which enters the seedling and jointing stage in spring. The annual average precipitation in spring is $30.2 \mathrm{~mm}$, which is less than $50 \mathrm{~mm}$, and so precipitation in spring becomes the maximum correlation factor affecting wheat production. Jointing stage of winter wheat is the key to a robust growth period, water demand is larger, precipitation of $20-50 \mathrm{~mm}$ in northwest of China can make jointing sound, and provide a good moisture condition. Precipitation of Qinghai fluctuates in this scope, the greater precipitation, the higher wheat yield.

June is the Key growing season for spring wheat in Inner Mongolia Autonomous Region. The precipitation of June has a positive correlation with crop yield in this region.

The soil moisture content during the seeding period is important for the crop. Enough precipitation before or during this period can benefit the crop yield in Gansu, Henan and Shanxi Province.

Precipitation in jointing stage in spring is also very important for winter wheat. There is a positive correlation between crop yield and precipitation in jointing stage in Shaanxi, Shanxi and Henan Province.

All in all, most of the time precipitation needed in each growing season is different in most parts of the Yellow River Basin, lack of precipitation is a major constraint normal growth factor.

Correlation analysis of meteorological factors affecting wheat climate relevant productivity

Without taking into account changes in solar radiation, regarding the temperature and precipitation as the most important factors related to wheat production, we can establish the following linear regression equation; all equations are adopted $\mathrm{F}$ distribution test with confidence of more than 95\% (Table 2).

Wheat climate relevant productivity in most of the regions in the Yellow River basin has a negative correlation with temperature, and is positively correlated with precipitation, which means wheat production declines significantly as temperature rises and precipitation drops.

The reduced production of wheat would bring about risks of national food security. To this end, technology improvement should be strengthened to raise wheat climate relevant productivity; water management should be enhanced and water-saving irrigation area should be increased to maximize water use efficiency and effectiveness in the existing water supply conditions.

Table 2. Multiple Regression Relationship between Meteorological factors and Wheat Climate relevant productivity.

\begin{tabular}{llcc}
\hline Region & Regression Function & Adjusted $\mathrm{R}^{2}$ & Sig. \\
\hline Qinghai & $\mathrm{Y}=-23.27+0.94 \mathrm{P}_{\mathrm{Mar}}+0.23 \mathrm{P}_{\mathrm{May}}+0.18 \mathrm{P}_{\mathrm{Jul}}$ & 0.570 & 0.036 \\
Gansu & $\mathrm{Y}=8.952+0.24 \mathrm{P}_{\mathrm{Sep}}+1.84 \mathrm{~T}_{\text {Apr }}-2.45 \mathrm{~T}_{\text {May }}$ & 0.840 & 0.042 \\
Inner Mongolia & $\mathrm{Y}=3.186+0.76 \mathrm{P}_{\mathrm{Jun}}-2.36 \mathrm{~T}_{\text {Apr }}$ & 0.462 & 0.036 \\
Shaanxi & $\mathrm{Y}=6.716+0.95 \mathrm{P}_{\mathrm{Feb}}-2.12 \mathrm{~T}_{\mathrm{Oct}}$ & 0.509 & 0.032 \\
Shanxi & $\mathrm{Y}=-12.943+0.48 \mathrm{P}_{\text {Sep }}+0.89 \mathrm{P}_{\mathrm{Feb}}+0.39 \mathrm{P}_{\mathrm{Mar}}$ & 0.384 & 0.028 \\
Henan & $\mathrm{Y}=-7.737+1.04 \mathrm{P}_{\mathrm{Oct}}+0.59 \mathrm{P}_{\mathrm{Feb}}$ & 0.847 & 0.008 \\
\hline
\end{tabular}

Notes: Y, Climate relevant productivity $\left(\mathrm{kg} \mathrm{ha}^{-1}\right) ; \mathrm{T}$, Temperature $\left({ }^{0} \mathrm{C}\right) ; \mathrm{P}$, Precipitation $(\mathrm{mm})$. 
The previous sections discuss mainly the linear correlation relation between climate relevant crop productivity and various factors, such as temperature and precipitation in the whole growing period, the different seasons, we have reaches the following conclusions:

(1) The main meteorological factor affecting climate relevant productivity of wheat is precipitation, crop yield rises with the increase of precipitation in the arid and semi-arid region in the northwest of the Yellow River basin which is lack of precipitation. North China is located in humid and sub-humid areas where rainfall is abundant, but precipitation still cannot meet water demand for crop to desire a large number of water in the growing season.

(2) Spring temperature which is too low and too high is both adverse conditions for the normal growth of wheat, temperature is sufficient to meet the growth of crops in most parts of the Yellow River Basin. The higher the temperature, the worse crop yields.

Wheat output changes in future in $A 2$ and $B 2$ scenarios

This section focuses on impacts of climate change in the future on wheat, preliminarily assess the impacts of climate change on crop production.

According to projections provided by our colleague, temperature and precipitation values in the growing season in 2050 in A2 and B2 scenario can be gathered, which are substituted into the multiple regression equation, climate relevant crop productivity in different weather situations can be calculated out.

Table 3. Projected climate relevant productivity under different scenarios in the future ( $\left.\mathrm{kg} \mathrm{ha}^{-1}\right)$.

\begin{tabular}{lcccc}
\hline \multirow{2}{*}{ Region } & \multicolumn{2}{c}{2050} & \multicolumn{2}{c}{2100} \\
\cline { 2 - 5 } & A2 Scenario & B2 Scenario & A2 Scenario & B2 Scenario \\
\hline Qinghai & 138 & 136.35 & 158.1 & 154.05 \\
Gansu & 97.8 & 112.8 & 87.9 & 108 \\
Inner Mongolia & -153.45 & -142.5 & -190.8 & -158.7 \\
Shaanxi & -62.4 & -14.4 & -126.9 & -37.2 \\
Shanxi & 129.45 & 205.2 & 172.35 & 238.35 \\
Henan & -14.25 & -20.7 & 2.25 & -12.9 \\
\hline
\end{tabular}

Benefit from the increase in precipitation, climate relevant crop productivity will rise in Qinghai, Gansu and Shanxi Province. However, in Inner Mongolia Autonomous Region and Shaanxi Province, the negative effect of the rising temperature plays a more important role to reduce the crop output. In Henan Province, climate change does not show significant effect on crop output.

Combining with the planting area of wheat in 2007, the effect of climate change on wheat yield for the Yellow River Basin can be calculated.
As showed in Table 4, Gansu and Shanxi Province will benefit from climate change mostly, while Inner Mongolia and Shaanxi Province will suffer the largest yield lose. As to the whole Basin, A2 scenario projected yield reduction, will B2 scenario projected yield increment. The extent of the impact of climate change on wheat yield in the Yellow River Basin is slight according to this study. However, the uncertainty of climate change itself and its impact on crop yield still need to be reduced. 
Table 4. Projected wheat yield under different scenarios in the future (t).

\begin{tabular}{lcccc}
\hline \multirow{2}{*}{ Region } & \multicolumn{2}{c}{2050} & \multicolumn{2}{c}{2100} \\
\cline { 2 - 5 } & A2 Scenario & B2 Scenario & A2 Scenario & B2 Scenario \\
\hline Qinghai & 21252 & 20998 & 24347 & 23724 \\
Gansu & 96053 & 110785 & 86330 & 106070 \\
Inner Mongolia & -81850 & -76010 & -101773 & -84651 \\
Shaanxi & -71423 & -16482 & -145250 & -42579 \\
Shanxi & 92203 & 146157 & 122759 & 169769 \\
Henan & -74290 & -107916 & 11730 & -67252 \\
Total & -18056 & 77532 & -1856 & 105081 \\
\hline
\end{tabular}

\section{Conclusions}

This study analyzes the relationship between winter wheat yield and average monthly temperature in the provinces of the Yellow River Basin and presents a forecasting model, draws the following conclusions:

Gansu Province, Qinghai Province, Ningxia Hui Autonomous Region and Inner Mongolia Autonomous Region belong to arid and semi-arid regions, lacking spring rainfall; the weather is changeable, and cold is apt to occur in late spring; the main constraints on the climate production of wheat are spring temperature and precipitation. Henan Province is located in a humid and semihumid area, with more rainfall, but it still can not meet the demand for wheat growth, indicating that precipitation is the main constraint factor for wheat in the basin.

Extreme low temperatures and high temperatures in spring are detrimental to the growth of wheat, and temperatures in most parts of the Yellow River are high enough to accommodate crop growth. The higher the temperature, the lower the crop yield. Benefiting from the increase in precipitation, climate-related crop productivity in Qinghai, Gansu and Shanxi provinces will increase. However, in the Inner Mongolia Autonomous Region and Shaanxi Province, the negative effects of elevated temperatures play a more important role in reducing crop yields.
For the entire basin, the A2 scenario expects a decrease in production, while the B2 scenario expects an increase in production. According to this study, climate change has little effect on wheat yield in the Yellow River Basin. However, the uncertainty of climate change itself and its impact on crop yields need to be reduced.

\section{References}

BENHIN, J. K. A. South African crop farming and climate change: An economic assessment of impacts. Global Environmental Change, Amsterdam, v. 4, n. 18, p. 666-678, 2008.

CHEN, L.; BAI, Z.; KONG, S. A land use regression for predicting $\mathrm{NO} 2$ and PM10 concentrations in different seasons in Tianjin region, China. Journal of Environmental Sciences, Beijing, v. 9, n. 22, p. 13641373, 2010.

CHINA AGRICULTURAL DATA SHARING CENTRE - AGRIDATA. Beijing. ano. Available at: $<$ http://www.agridata.cn/data/datacontent.aspx?data par $=12610642014062700002>$. Accessed at: 13 aug. 2018.

DU, W.; WANG, X. Potential wind erosion rate response to climate and land-use changes in the watershed of the Ningxia-Inner Mongolia reach of the Yellow River, China, 1986-2013. Earth Surface Processes and Landforms, Beijing, v. 3, n. 42, p. 1923-1937, 2017.

FICKLIN, D. L.; LUO, Y.; LUEDELING, E. Climate change sensitivity assessment of a highly agricultural watershed using SWAT. Journal of Hydrology, Amsterdam. v. 1, n. 274, p. 16-29, 2009. 
FISCHER, G.; TUBIELLO, F. N.; VAN, VELTHUIZEN, H. Climate change impacts on irrigation water requirements: effects of mitigation, 1990-2080. Technological Forecasting and Social Change, Amsterdam, v. 7, n. 74, p. 1083-1107, 2007.

HATFIELD, J. L.; DOLD, C. Agroclimatology and wheat production: coping with climate change. Frontiers in Plant Science, Beijing, v. 3, n. 9, p. 14-18, 2018.

HUSSAIN, K.; AHMAD, A. Wheat responses to climate change and its adaptations: a focus arid and semi-arid environment. International Journal of Environmental Research, Tehran, v. 12, n. 9, p. 117-126, 2018.

LIANG, F.; PEI, L.; LI, Y. Demographic expansion of two Tamarix species along the yellow river caused by geological events and climate change in the Pleistocene. Scientific Reports, Beijing, v. 8, n. 1, p. 23-35, 2018.

LUDWIG, F.; ASSENG, S. Climate change impacts on wheat production in a Mediterranean environment in Western Australia. Agricultural Systems, Oxford, v. 3, n. 9, p. 159-179, 2006.

LUO, Y.; SHERRY, R.; ZHOU, X.; WAN, S. Terrestrial carbon $\square$ cycle feedback to climate warming: experimental evidence on plant regulation and impacts of biofuel feedstock harvest. Gcb Bioenergy, Malden, v. 1, n. 1, p. 62-74, 2009.

LYU, Z.; ZHANG, S. Impacts of climate change on runoff in the Yellow River. Journal American Water Works Association, Wuhan, v. 106, n. 4, p. 225-232, 2014.

MASUTOMI, Y.; TAKAHASHI, K.; HARASAWA, H. Impact assessment of climate change on rice production in Asia in comprehensive consideration of process/ parameter uncertainty in general circulation models. Agriculture, Ecosystems \& Environment, Amsterdam, v. 3, n. 13, p. 281-291, 2009.

MENG, S.; YANG, T.; TONG, H. Impacts of recent climate change on the hydrology in the source region of the Yellow River basin. Journal of Hydrology-Regional Studies, Nanjing, v. 6, n. 1, p. 66-81, 2016.

MESTRE-SANCHÍS, F.; FEIJÓO-BELLO, M. L. Climate change and its marginalizing effect on agriculture. Ecological economics, Amsterdam, v. 3, n. 68, p. 896-904, 2009.

MIRAGLIA, M.; MARVIN, H. J. P.; KLETER, G. A. Climate change and food safety: an emerging issue with special focus on Europe. Food and chemical toxicology, Oxford, 2 v. 5, n. 47, p. 1009-1021, 2009.

PAN, T.; WU, S.; LIU, Y. Relative contributions of land use and climate change to water supply variations over Yellow River source area in tibetan plateau during the past three decades. Plos One, San Francisco, v. 10, n. 1, p. 21-34, 2015.

PAYMARD, P.; BANNAYAN, M.; HAGHIGHI, R. Analysis of the climate change effect on wheat production systems and investigate the potential of management strategies. Natural Hazards, New York, v. 1, n. 91, p. 1237-1255, 2018.

REIDSMA, P.; EWERT, F.; LANSINK, A. O.; LEEMANS, R.; WERY, J.; LANGEVELD, J. W. A. Adaptation to climate change and climate variability in european agriculture: the importance of farm level responses. European Journal of Agronomy, Amsterdam, v.1, n.32, p. 91-102, 2010.

REZAEI, S.; HUGING, E.; HUGING, H.; EWERT, F. Climate change effect on wheat phenology depends on cultivar change. Scientific Reports, Beijing, v. 5, n. 8, p. 44-52, 2018.

SU, L. Yellow river action on climate changes. Proceeding of the 5th International Yellow River Forum on Ensuring Water Right of the River's Demand and Healthy River Basin Maintenance, v. 1, n. 3, p. 29-33, 2015.

WANG, L.; WU, Y.; LI, W. Spatiotemporal analysis of temperature trends under climate change in the source region of the Yellow River, China. Theoretical and Applied Climatology, Beijing, v. 1, n. 19, p. 123-133, 2015.

WEI, X.; DECLAN, C.; ERDA, L. Future cereal production in China: the interaction of climate change, water availability and socio-economic scenarios. Global Environmental Change, v. 2, n. 19, p. 34-44, 2009.

WU, B.; ZHOU, T.; LI, T. Seasonally evolving dominant interannual variability modes of East Asian climate. Journal of Climate, Boston, v. 11, n. 22, p. 2992-3005, 2009.

YANG, S.; ZHANG, Z.; KOUSKY, V. E. Simulations and seasonal prediction of the Asian summer monsoon in the NCEP Climate Forecast System. Journal of Climate, Boston, v. 15, n. 21, p. 3755-3775, 2008.

YU, Z.; BEILMAN, D. W.; JONES, M. C. Sensitivity of northern peatland carbon dynamics to Holocene climate change. Carbon cycling in northern peatlands, Geophysical Monograph, Beijing, v. 184, n. 1, p. 55-69, 2013.

ZHAO, L.; LEE, X.; SMITH, R. B. Strong contributions of local background climate to urban heat islands. Nature, London, v. 7508, n. 511, p. 216, 2014. 